\title{
Correction to: Individual and structural correlates of willingness for intravenous buprenorphine treatment among people who inject sublingual buprenorphine in France
}

Salim Mezaache ${ }^{1,2^{*}}$, Patrizia Carrieri ${ }^{1,2}$, Laelia Briand-Madrid ${ }^{1,2}$, Virginie Laporte ${ }^{3}$, Alain Morel $^{4}$, Daniela Rojas Castro ${ }^{1,2,5}$ and Perrine Roux ${ }^{1,2}$

Correction to: Mezaache et al. Harm Reduct J (2021) 18:11 https://doi.org/10.1186/s12954-021-00460-0

Following publication of the original article [1], the authors identified an error in Table 1.

The correct table is given below.

The original article has been corrected. to the material. If material is not included in the article's Creative Commons licence and your intended use is not permitted by statutory regulation or exceeds the permitted use, you will need to obtain permission directly from the copyright holder. To view a copy of this licence, visit http://creativecommons.org/licenses/by/4.0/. The Creative Commons Public Domain Dedication waiver (http://creativeco mmons.org/publicdomain/zero/1.0/) applies to the data made available in this article, unless otherwise stated in a credit line to the data. 
Table 1 Factors associated with general willingness to receive intravenous buprenorphine treatment in the study sample

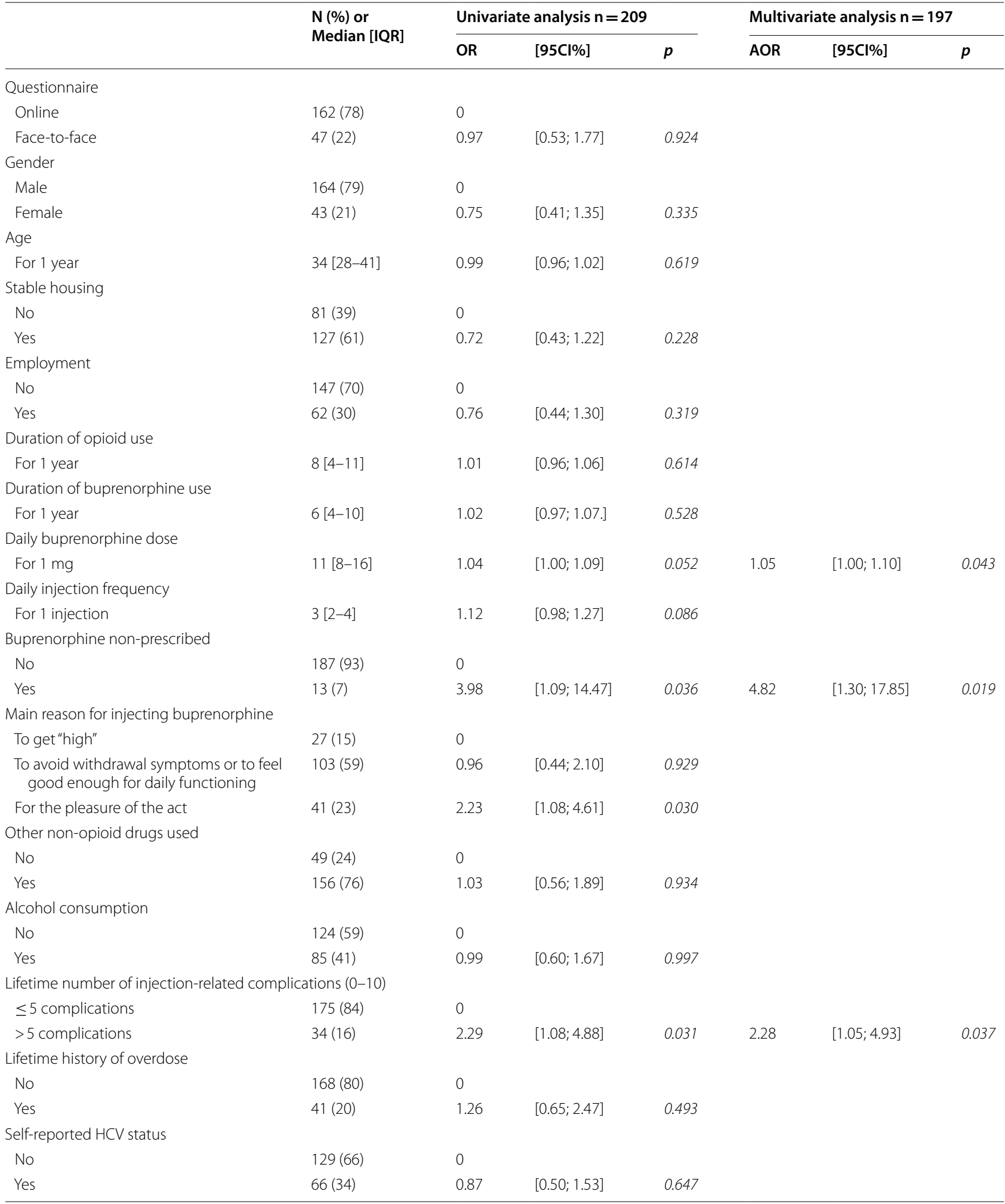




\section{Author details}

${ }^{1}$ INSERM, IRD, SESSTIM, Sciences Economiques \& Sociales de La Sante \& Traitement de L'information Medicale, Aix-Marseille Univ, Marseille, France.

2 ORS PACA, Observatoire Regional de La Sante Provence-Alpes-Cote D'Azur, Marseille, France. ${ }^{3}$ Aides, Pantin, France. ${ }^{4}$ Association Oppelia, Paris, France.

${ }^{5}$ Laboratoire de Recherche Communautaire Coalition PLUS, Pantin, France.

Published online: 19 February 2021

\section{Reference}

1. Mezaache et al. Harm Reduct J (2021) 18:11. https://doi.org/https://doi. org/10.1186/s12954-021-00460-0

\section{Publisher's Note}

Springer Nature remains neutral with regard to jurisdictional claims in published maps and institutional affiliations. 